\title{
Use of labetalol and glyceryl trinitrate for induced hypotension in spine surgery- A comparative study
}

\section{Sabina Yeasmeen ${ }^{*}$, Md. Rafayet Ullah Siddique ${ }^{1}$, Amirul Islam², AKM Aktaruzzaman ${ }^{3}$, Debabrata Banik ${ }^{3}$, Abdul Hye ${ }^{3}$.}

${ }^{1}$ Assistant Professor, ${ }^{2}$ Medical Officer, ${ }^{3}$ Associate Professor, Department of Anaesthesia, Analgesis and Intensive Care Medicine, BSMMU, Dhaka

*Correspondence author, E-mail: yeasmeens@yahoo.com

\begin{abstract}
:
Background: Induced hypotension is used to reduce blood loss especially in those operations where even a small amount of blood can obscure the operative field such as spine surgery.
\end{abstract}

Objectives: To compare the effect of labetalol with that of glyceryl trinitrate to reduce intraoperative blood loss by inducing elective hypotension without any tachycardia and to improve quality of surgical field during spine surgery.

Method: A total number of thirty patients (ASA grade I \& II) were selected randomly into two groups,

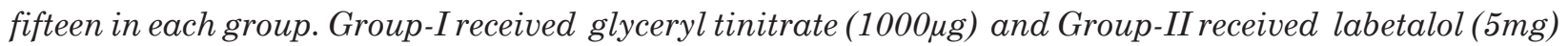
intravenously 3 minutes before induction of anaesthesia. Heart rate, mean arterial pressure was observed in two study groups 15 minutes interval in intra-operative period and quality of surgical field was detected by 4 points VRS (Verbal rating scale) after completion of surgery by asking the surgeon.

Results: Heart rate varied significantly in two study groups after induction of anaesthesia except baseline and pre induction $(p<0.05)$. Labetalol associated with improved quality of surgical field visualization than glyceryltrinitrate $(p=0.034)$.

Conclusion: Our study concluded that labetalol is effective than glyceryltrinitrate to reduce blood loss in spine surgery.

Key words: spine surgery, labetalol, glyceryltrinitrate, intraoperative period, quality of surgical field, mean arterial pressure, verbal rating scale.

(Journal of BSA, 2009; 22(2): 48-53)

\section{Introduction:}

Anaesthesia may influence intraoperative bleeding in several ways both physiologically and pharmacologically. Elective hypotension is used to reduce operative blood loss especially in those operations like spine surgery ${ }^{1}$, middle ear surgery, cerebro-vascular surgery where even a small quantity of blood can obscure the operative field and make difficulties for the surgeon for a good proper surgery and prolong duration of operation ${ }^{1}$. Laryngoscopic stimulation of oropharyngeal structure may be an important factor in the haemodynamic stress response associated with tracheal intubation. ${ }^{2}$
Instrumentation of pharynx and tracheal intubation may result in tachycardia, hypertension and increased plasma catecholamine concentration that may evoke life threatening condition among susceptible individuals especially those with cardiovascular disease. ${ }^{3}$ Hypotensive anaesthesia has long been established as safe as effective method for reducing blood loss upto $80 \%{ }^{4}$

Various types of pharmacological agents used to achieve hypotensive anaesthesia have been studied during spine surgery. They include ganglion blocking agents, volatile agent. ${ }^{5}$ Calcium channel blocker ${ }^{6}$, sodium nitropruside ${ }^{7}$, 
nitroglycerine ${ }^{8}, \alpha \& \beta$ adrenergic blocker ${ }^{9}$. Mean arterial pressure (MAP) is typically maintained at $60-70 \mathrm{mmHg}$. These drugs, however, are not entirely satisfactory, as tachyphylaxis and undesirable tachycardia often occur ${ }^{7}$. There is little evidence that any particular agent is superior but the avoidance of tachycardia is an essential part of a good anaesthetic technique.

Labaetalol is both $\alpha \& \beta$ adrenergic receptor blocker which reduces blood pressure without significant altering either resting heart rate or cardiac output $^{9}$. Glyceryl trinitrate alternative relaxes vascular smooth muscle with venous dilatation predominating over arterial dilatation reduces blood pressure by reducing preload but it causes reflex tachycardia ${ }^{6}$.

In our present study we compare the effects of labetalol with that of glyceryltrinitrate for safe elective hypotensive anaesthesia to reduce the blood loss so as to produce a clear surgical field during intraoperative period of spine surgery.

\section{Methods}

Study population:

Total 30 patients of type of spinal pathology scheduled for spinal surgery was recruited for the study. University departmental ethics committe give consent before carrying out the study. Informed consent were taken from all patients before the procedure.

After recruitment, thirty patients of both sex, male and female aged 15-60 years, ASA grade I and II divided in two groups. Fifteen patients in each group. Patients were randomly divided into two groups. According to card number, patients grouped. Patients with history of bronchospasm, significant ventricular hypertrophy, Sinus bradycardia ( $<45-50$ beats/min), allergic rhinitis, $2^{\text {nd }}$ and $3^{\text {rd }}$ degree heart block, congestive heart failure, diabetes mellitus were excluded from this study.

Patients data were collected from pre anaesthetic assessment audit form. Preoperative parameters (pulse rate, systolic and diastolic blood pressure, mean arterial pressure, $\mathrm{SpO}_{2}$ ) were recored. Intravenous canula inserted on left hand. After recording pulse, blood pressure, $\mathrm{SpO}_{2}$, Group-I received glyceryl trinitrate $(1000 \mu \mathrm{g})$ and Group-II was received inj. Labetalol $(5 \mathrm{mg})$ intravenously 3 minutes before induction of anaesthesia.

Pre-oxygenation was done for 3-5 minutes with $100 \%$ oxygen, induction of anaesthesia was done with fentanyl $(1 \mu \mathrm{g} / \mathrm{kg})$ and thiopentone sodium $(5 \mathrm{mg} / \mathrm{kg})$ and endotracheal intubation was done by suxamethonium $(1.5 \mathrm{mg} / \mathrm{kg})$. Maintenance of anaesthesia with $\mathrm{N}_{2} \mathrm{O} 70 \%, \mathrm{O}_{2} 30 \%$ and halothane $(0.5 \%-1 \%)$ with non depolarizing neuromuscular blocking agent vecuronium bromide $(0.1 \mathrm{mg} / \mathrm{kg})$ incremental dose of fentanyl $(0.3-0.4 \mu \mathrm{g} / \mathrm{kg})$ was given as needed. Intraoperative fluid was maintained with Hartmann's solution or normal saline. Intraoperatively 15 minutes interval pulse rate, systolic and diastolic blood pressure and mean arterial pressure observed. Mean arterial pressure was maintained at 70-80 mmHg. Quality of surgical field was observed by points VRS (Verbal rating scale) (1. Not satisfactory 2. Moderate satisfactory, 3. Good, 4. Excellent) and detected by asking the surgeon after completion of surgery. In Group-I glyceryl trinitrate $(1000 \mu \mathrm{gm})$ given at 15 minutes interval and also given as required to maintain desired mean arterial pressure and in Group- II. labetalol $(5 \mathrm{mg})$ given at 30 minutes interval also given as required. Operation time was on average about two hours.

\section{Statistical Analysis:}

All the variables were expressed as mean \pm SD. Student t-test and chi-square $\left(\chi^{2}\right)$ test were done as the tests of significance where applicable to compare the mean of different groups. The statistical analysis was done by using SPSS programme. P value < 0.05 was considered as significant.

\section{Results:}

Observation of the present study was analyzed in the light of comparison among each subject groups. Each group having $\mathrm{n}=15$. All results were expressed as mean $\pm \mathrm{SE}$ or in frequencies as applicable. The groups became statistically matched for age $(p=0.366)$, weight $(p=0.697)$, sex $(p=.705)$. ASA grading $(p=0.713)$. There was no significant difference among the study groups. 
Table-I

Demographic data of two stud y group.

\begin{tabular}{llccc}
\hline Group/variable & & Group-I(n=15) & Group-II(n=15) & P value \\
\hline Age (years) & & $41.27 \pm 2.809$ & $38.07 \pm 2.046$ & 0.366 \\
Weight $(\mathrm{kg})$ & & $60.20 \pm 3.854$ & $62.07 \pm 2.763$ & 0.697 \\
Sex & Male & $9(60.0)$ & $10(66.7)$ & 0.705 \\
& Female & $6(40.0)$ & $5(33.3)$ & \\
ASA & $\mathrm{I}$ & $8(53.3)$ & $9(60.0)$ & 0.713 \\
& $\mathrm{II}$ & $7(46.7)$ & $6(40.0)$ & \\
\hline
\end{tabular}

Data was analyzed by unpaired students ' $\mathrm{t}$ ' test, Values are regarded significant $\mathrm{P}<0.05$.

Table-II

Changes of heart rate in two study group.

\begin{tabular}{lcccccccccc}
\hline & Baseline & $\begin{array}{c}\text { Pre- } \\
\text { induction }\end{array}$ & $\begin{array}{c}15 \mathrm{~min} \\
\text { after } \\
\text { induction }\end{array}$ & $\begin{array}{c}30 \mathrm{~min} \\
\text { after }\end{array}$ & $\begin{array}{c}45 \mathrm{~min} \\
\text { after }\end{array}$ & $\begin{array}{c}60 \mathrm{~min} \\
\text { after }\end{array}$ & $\begin{array}{r}75 \mathrm{~min} \\
\text { after }\end{array}$ & $\begin{array}{c}90 \mathrm{~min} \\
\text { after }\end{array}$ & $\begin{array}{c}105 \mathrm{~min} \\
\text { after }\end{array}$ & $\begin{array}{c}120 \mathrm{~min} \\
\text { after }\end{array}$ \\
& & & & induction & induction & induction & induction & induction induction \\
Group-I & $81.80 \pm$ & $85.60 \pm$ & $90.93 \pm$ & $86.07 \pm$ & $84.40 \pm$ & $80.80 \pm$ & $78.93 \pm$ & $82.85 \pm$ & $74.40 \pm$ & $68.00 \pm$ \\
(n=15) & 2.219 & 2.276 & 2.074 & 2.804 & 2.348 & 2.487 & & 2.6452 .780 & 3.855 & 0.0 \\
Group-II & $82.13 \pm$ & $83.07 \pm$ & $82.73 \pm$ & $74.67 \pm$ & $74.07 \pm$ & $68.73 \pm$ & $69.73 \pm$ & $67.27 \pm$ & $64.33 \pm$ & $65.00 \pm$ \\
(n=15) & 1.633 & 2.525 & 2.817 & 2.937 & 3.586 & 2.504 & 2.381 & 1.832 & 2.042 & 2.408 \\
t-value & .121 & .745 & 2.344 & 2.808 & 2.411 & 3.419 & 2.585 & 4.679 & 2.308 & .509 \\
P-value & $.905^{\mathrm{ns}}$ & $.462^{\mathrm{ns}}$ & $.027^{\mathrm{s}}$ & $.009^{\mathrm{s}}$ & $.024^{\mathrm{s}}$ & $.002^{\mathrm{s}}$ & $.015^{\mathrm{s}}$ & $.001^{\mathrm{s}}$ & $.058^{\mathrm{s}}$ & $.638^{\mathrm{ns}}$ \\
\hline
\end{tabular}

Values are expressed as mean \pm SD. Data are analyzed by student $t$ test, values are regarded as significant $\mathrm{P}<0.05 . \mathrm{ns}=$ non significant, $\mathrm{s}=$ significant

Baseline mean heart rate in Group-I was

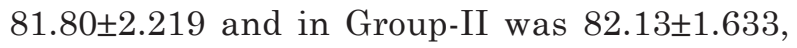
where, $\mathrm{p}=0.905$ (Table-II).

Pre-induction mean heart rate in Group-I was 85.60 \pm 2.276 and in Group-II 83.07 \pm 2.525 , where $\mathrm{p}=0.462$.

Heart rate of two studied groups are displayed, where baseline and pre-induction values were not significantly difference in two groups.

Heart rate varied significantly at $15 \mathrm{~min}(\mathrm{p}=0.027)$, $30 \min (\mathrm{p}=0.009), 45 \min (\mathrm{p}=0.024), 60 \min (\mathrm{p}=$ $0.002), 75 \min (p=0.015), 90 \min (p=0.001)$ after induction of anaesthesia.

Heart rate of two study groups displayed in Fig: I

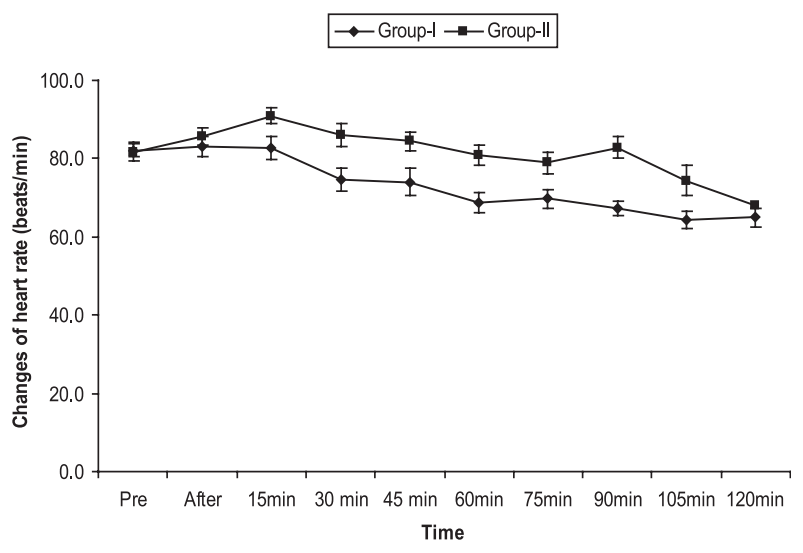

Fig. 1: Changes of heart rate in two study groups

Regarding heart rate there is slight increase in heart rate in group I. There was significant change in Fig.-1. 
Table-III

Changes of mean arterial pressure in two studies group.

\begin{tabular}{|c|c|c|c|c|c|c|c|c|c|c|}
\hline & Baseline & $\begin{array}{c}\text { Pre- } \\
\text { induction }\end{array}$ & $\begin{array}{l}\text { 15min } \\
\text { after }\end{array}$ & $\begin{array}{l}30 \text { min } \\
\text { after }\end{array}$ & $\begin{array}{l}45 \text { min } \\
\text { after }\end{array}$ & $\begin{array}{l}60 \mathrm{~min} \\
\text { after }\end{array}$ & $\begin{array}{l}75 \mathrm{~min} \\
\text { after }\end{array}$ & $\begin{array}{l}90 \mathrm{~min} \\
\text { after }\end{array}$ & $\begin{array}{c}105 \mathrm{~min} \\
\text { after }\end{array}$ & $\begin{array}{c}120 \mathrm{~min} \\
\text { after }\end{array}$ \\
\hline & & & induction & induction & induction & induction & induction & induction & induction & induction \\
\hline \multirow[t]{2}{*}{ Group-I } & $101.00 \pm$ & $97.00 \pm$ & $97.07 \pm$ & $86.00 \pm$ & $78.93 \pm$ & $86.60 \pm$ & $84.80 \pm$ & $85.92 \pm$ & $83.33 \pm$ & $84.33 \pm$ \\
\hline & 2.591 & 2.908 & 4.975 & 2.878 & 3.051 & 4.591 & 3.234 & 2.690 & 3.333 & 3.333 \\
\hline \multirow[t]{2}{*}{ Group-II } & $98.27 \pm$ & $93.40 \pm$ & $80.33 \pm$ & $77.93 \pm$ & $77.67 \pm$ & $75.93 \pm$ & $78.13 \pm$ & $80.83 \pm$ & $81.00 \pm$ & $82.00 \pm$ \\
\hline & 3.724 & 3.634 & 1.985 & 1.666 & 2.352 & 1.578 & 2.204 & 2.063 & .577 & .577 \\
\hline t-value & .602 & .773 & 3.124 & 2.425 & .329 & 2.197 & 1.704 & 1.501 & .690 & .590 \\
\hline P-value & $.552^{\mathrm{ns}}$ & $.446^{\mathrm{ns}}$ & $.006^{\mathrm{s}}$ & $.024^{\mathrm{s}}$ & $.745^{\mathrm{ns}}$ & $.042^{\mathrm{s}}$ & $.101^{\mathrm{ns}}$ & $.147^{\mathrm{ns}}$ & $.558^{\mathrm{ns}}$ & $.548^{\mathrm{ns}}$ \\
\hline
\end{tabular}

Values are expressed as mean \pm SD. Data are analyzed by student $t$ test, value are regarded as significant $\mathrm{P}<0.05$.

Baseline mean arterial pressure in Group I was $101.00 \pm 2.951$ and in Group II was $98.27 \pm 3.591$ where $\mathrm{p}=0.552$ (Table-III).

Pre-induction mean arterial pressure in Group-I was 97.00 \pm 2.908 and in Group-II 93.40 \pm 3.634 where $\mathrm{p}=$ 0.446 .

Mean arterial pressure of two studied groups are displayed, where baseline and pre-induction values were not significantly different in two groups, but varied significantly at $15 \mathrm{~min}(\mathrm{p}=0.006), 30 \mathrm{~min}(\mathrm{p}$ $=0.024), 60 \mathrm{~min}(\mathrm{p}=0.042)$ after induction of anaesthesia.

Mean arterial pressure of study groups is displayed in Fig: II.

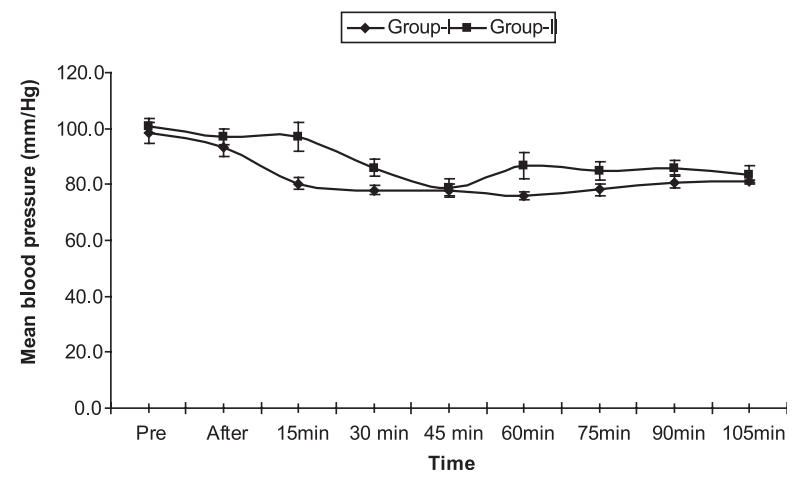

Fig.-2: Changes of mean arterial pressure in two study groups

Regarding mean arterial pressure there is slight change in two groups. The difference between two groups are not significant showed in Fig: 2.

\section{Table-IV}

Quality of surgical field by verbal rating scale (VRS) in two study groups.

\begin{tabular}{lccccc}
\hline & Group-I & Group-II & Total & $\chi^{2}$-value & P-value \\
\hline Not satisfactory & $3(20.0 \%)$ & $0(.0 \%)$ & $3(10.0 \%)$ & & \\
Moderate satisfactory & $8(53.3 \%)$ & $4(26.7 \%)$ & $12(40.0 \%)$ & & \\
Good & $426.7 \%$ & $8(53.3 \%)$ & $12(40.0 \%)$ & 8.667 & $0.034^{\mathrm{s}}$ \\
Excellent & $0(.0 \%)$ & $3(20.0 \%)$ & $3(10.0 \%)$ & & \\
\hline Total & $15(100.0 \%)$ & $15(100.0 \%)$ & $30(100.0 \%)$ & & \\
\hline
\end{tabular}

Data analyzed by chi-square $\left(\chi^{2}\right)$ test, value are regarded as significant $(\mathrm{P}<0.05)$.

Improved quality of surgical field visualization was detected after completion of surgery by asking the surgeon by verbal rating scale (VRS). "Bleeding obscure surgical field" group I =3, group II= 0. Moderate 
bleeding obscure surgical field group I =8, group $\mathrm{II}=4$, Mild bleeding but surgical field is clear group $\mathrm{I}=4$, group $\mathrm{II}=8$, Excellent surgical field group $\mathrm{I}$ $=0$, group $\mathrm{II}=3$ (Table-IV).

Group-II associated with significant improved quality of surgical field ( $\mathrm{p}=0.034)$.

\section{Discussion:}

Elective hypotension is a specific anaesthetic technique which goes beyond the ability of a good, safe, non-stress-inducing anaesthetic to reduce blood loss. Its use may be classified broadly as applicable to situations in which the particular operation would otherwise be impossible (for example cardiovascular or cerebrovascular surgery), Situations in which excessive blood loss might be detrimental(for example orthopaedics, spinal, and maxillo-facial operations) and situations in which blood loss interferes with surgical visibility or technique(such as middle ear surgery and spine surgery).

Bloodless surgical field helps the surgeon to operation in short time and without damage of any important nerve roots due to clear visible surgical field.

The benefits of induced hypotension during spine surgery include reduction in blood loss and also reduce need for blood transfusion, improved quality of surgical field and shorter duration of surgery. A number of hypotensive agents have been studied include ganglion blocking agents, volatile agents, calcium channel blocker, sodium nitropruside, nitroglycerine, â-blocker. These drugs however are not entirely satisfactory as tachyphylaxis or undesirable tachyardia often occur ${ }^{6}$.

Labetalol has stereoisomers ${ }^{9,10,14}$. It is a racemic mixture of four isomers. Two of these isomers, the (S,S)- and (R,S)- forms are inactive. The third, the $(\mathrm{S}, \mathrm{R})$-isomer, is a powerful $\alpha_{1}$ blocker. The fourth isomer, the $(R, R)$-isomer, is a mixed nonselective $\beta$ blocker and selective $\beta_{2}$ antagonist.

It works by blocking these adrenergic receptors, which decreases peripheral vascular resistance without significantly altering heart rate or cardiac output. ${ }^{9}$ The $\alpha: \beta$ antagonism of Labetalol is approximately $3: 1^{15,16}$. Glyceryl causes venous dilatation predominating over arterial dilatation reduced blood pressure by reducing preload but it causes reflex tachycardia ${ }^{6,13}$.
Kadam $\mathrm{PP}^{12}$ studied hypotensive anaesthesia for spine surgery comparing nitroglycerine vs halothane. In this prospective study 30 patients (ASA I or II) requiring spine surgery under general anaesthesia were studied. Group-I received halothane $0.5-2.5 \%$ and group- II received intravenous nitroglycerine infusion $1-2 \mu \mathrm{g} / \mathrm{kg} / \mathrm{min}$. They studied blood pressure, blood loss, operating time and recovery score. In their study there was no significant between groups differences in patients demographic data. There was no significant difference in haemodynamic parameters. The blood loss with nitroglycerine was significantly less (202 $\pm 114 \mathrm{ml})$ than halothane groups $(602 \pm 312 \mathrm{ml})$. All the patients were alert at the end of surgery in nitroglycerine groups (recovery score $9.8 \pm 0.76$ ) as against the halothane groups $(7.98 \pm 0.9)(p<0.01)$.

By comparing with this study, in our study we found there were no significant difference between groups in patients demographic data and less blood loss in Labetalol group. Kaplan et $\mathrm{al}^{13}$ did not observe significant change in heart rate when nitroglycerine was used to control blood pressure during coronary artery surgery. They suggested that gradual reduction in blood pressure by nitroglycerine prevented an increase in heart rate. But in our study heart rate varied significantly at $15 \min (\mathrm{p}=0.027), 30 \mathrm{~min}(\mathrm{p}=0.009), 45 \mathrm{~min}(\mathrm{p}$ $=0.024), 60 \mathrm{~min}(\mathrm{p}=0.002), 75 \mathrm{~min}(\mathrm{p}=0.015), 90$ $\min (p=0.001)$ after induction of anaesthesia except base line and pre induction.

There was no significant difference in mean arterial pressure between groups except $15 \mathrm{~min}(\mathrm{p}=0.006)$, $30 \min (p=0.024), 60 \mathrm{~min}(\mathrm{p}=0.042)$, after induction of anaesthesia.

Also in our study labetalol was associated with improved quality of surgical field than glyceryltrinitrate $10 \%, 0 \%$ respectively $(\mathrm{p}=0.034)$.

In our study, 1 patient in labetalol group, 2 patients in glyceryltrinitrate required blood transfusion.

So from above observation we found that heart rate remains stable in labetalol group than glyceryltrinitrate intraoperatively. Mean arterial pressure was maintained at $70-80 \mathrm{~mm}$ of $\mathrm{Hg}$ in labetalol group. Dose requirement and time interval decrease in labetalol group and also decrease the requirement of blood transfusion.

So our result showed that labetalol $(5 \mathrm{mg})$ administered intravenously 3 minutes before 
induction of anaesthesia is effective than glyceryltrinitrate to reduce blood loss intraoperatively and improved quality of surgical field in spine surgery.

\section{Conclusion:}

Under the condition of present study, it was found that intravenous labetalol is a more safe hypotensive agent in comparison to glyceryltrinitrate in spine surgery.

\section{References:}

1. Grundy BL, Nash CL, Brown RH. Deliberate hypotension for spinal fusion. Prospective randomized study with evoked potential monitoring. Cand Anaesth J 1982; 29: 452462

2. Forbes AM, Dally FG. Acute hypertension during induction and endotracheal intubation in normotensive man. Br J Anaesth 1970; 42: $18-628$.

3. Prys-Roverst SG, Green LT, Neloche R, Foep. Study of anaesthesia in relation to hypertension hyperdynamic consequences of induction of endotracheal intubation. Br J Anaesth 1971; 43: 531-547. .

4. Malcolm- Smith NA, Mack Master MJ. The use of induced hypotension to control bleeding during posterior fusion for scoliosis. J Bone Joint Surg 1983; 65: 255-8.

5. Tobias JD. Sevoflurance for controlled hypotension during spine surgery: Preliminary experience in five adolescents Paediats Anaesth 1998; 2 ; 167-70.

6. Her Sey SL, O' Dell NE, Dowe S, et al. Nicardipine Versus nitroprusside for controlled hypotension during spinal surgery in adolescents. Anas Analg 1997; 84: 1239-44.
7. Bale R, Powler A, Nyatt R. Intravenously glyceryltrinitrate haemodynamic effect clinical use in cardiac surgery. Br J Anaesth 1982; 54: 297-301.

8. Richards DA, Prichard, BNC, Boaker AJ, Tuckman JE, Knigh EJ. Pharmacological basis for antihypertensive effects of intravenous Labetalol, Br Heart J 1977; 39: 99-106.

9. Scott, DB, Budkleg, FOUND, Drummono GB, Little Wood, DGE Macrae WR et al. Cardiovascular effects of Labetalol during halothane Anaesthesia. Br J Clin Pharmac 1976; 3: 817-821.

10. Jones SER. Controlled hypotension using labetalol and halothane anaesthesia 1979; 34: 1052-1055.

11. Uirich PE Jr, Keene JS, Hogan KJ, Rocekor FB. Results of hypotensive anaesthesia in operative treatment thoracol umber fractures. J Spinal Disord 1990; 3: 329-33.

12. Kadam PP, Sakesena SG, Jagtap SR, Pantavaidya SM. Hypotensive anaesthesia for spine surgery. J Postgrade Med 1993; 39(1): 2628.

13. Kalplan JA, Dunbar RW, Jones EL. Nitroglycerin as a hypotensive drug during general anaesthesia. Anaesthesiology 1978; 20: 17-20.

14. Riva E, Mennini T, Latini $R$.The alpha- and beta-adrenoceptor blocking activities of labetalol and its RR-SR (50:50) stereoisomers. Br. J. Pharmacol 1991; 104 (4): 823-8.

15. Katzung, Bertram G. Basic and clinical pharmacology. New York: McGraw-Hill Medical. 2006; p. 170.

16. D A Richards, J Tuckman, and B N Prichard. Assessment of alpha- and beta-adrenoceptor blocking actions of labetalol. Br J Clin Pharmacol. 1976; 3 (5): 849-855. 